\title{
Inflammatory pseudotumor of the Kidney
}

\section{David R Selvan ${ }^{1}$, Joe Philip*1, Ramaswamy Manikandan'1, Timothy R Helliwell ${ }^{2}$, Gabriel HR Lamb ${ }^{3}$ and Anthony D Desmond ${ }^{1}$}

Address: ${ }^{1}$ Department of Urology, Royal Liverpool University Hospital, Liverpool, UK, ${ }^{2}$ Department of Pathology, Royal Liverpool University Hospital, Liverpool, UK and ${ }^{3}$ Department of Radiology, Royal Liverpool University Hospital, Liverpool, UK

Email: David R Selvan - daveselvan@doctors.org.uk; Joe Philip* - indianajoe@gmail.com;

Ramaswamy Manikandan - armanikan2000@gmail.com; Timothy R Helliwell - timothy.helliwell@rlbuht.nhs.uk;

Gabriel HR Lamb - gaby.lamb@rlbuht.nhs.uk; Anthony D Desmond - anthony.desmond@rlbuht.nhs.uk

* Corresponding author

Published: 24 September 2007

World Journal of Surgical Oncology 2007, 5:106 doi:10.1 186/1477-7819-5-106

This article is available from: http://www.wjso.com/content/5/I/106

(C) 2007 Selvan et al; licensee BioMed Central Ltd.

This is an Open Access article distributed under the terms of the Creative Commons Attribution License (http://creativecommons.org/licenses/by/2.0), which permits unrestricted use, distribution, and reproduction in any medium, provided the original work is properly cited.
Received: 23 january 2007

Accepted: 24 September 2007

\begin{abstract}
Background: Inflammatory pseudotumor of the kidney or inflammatory myofibroblastic tumor (IMT) is composed of spindle cells admixed with variable amount of proliferating myofibroblasts, fibroblasts, extracellular collagen, lymphocytes and plasma cells. This mainly affects the urinary bladder or prostate. Renal involvement is rare.

Case presentation: A 56 year-old man was diagnosed with asymptomatic left sided hydronephrosis while being investigated for rheumatoid arthritis. CT scan imaging showed ill defined fascial plains around the kidney and thickening around the renal hilum suggestive of localized inflammatory change. Worsening intermittent left loin pain with increasing hydronephrosis, significant cortical thinning and marked deterioration of renal function necessitated nephrectomy. Macroscopy showed a hydronephrotic fibrotic kidney with microscopy and immunohistochemistry consistent with a histological diagnosis of IMT.
\end{abstract}

Conclusion: We report a case of an inflammatory pseudotumor of the kidney. It is unique in that the patient presented with painless hydronephrosis followed two years later with progressive deterioration in renal function and worsening loin pain.

\section{Background}

Inflammatory myofibroblastic tumor (IMT) or pseudotumor is a rare benign tumor that can be seen in various organs. It is of unknown etiology and difficult to differentiate from malignancy. Histologically, there is evidence of marked proliferation of myofibroblasts, fibroblasts, histiocytes, and plasma cells. There have been no reports of recurrence.

We report a unique case of inflammatory pseudotumor of the kidney; the patient presented with painless hydrone- phrosis followed two years later with progressive deterioration in renal function and worsening loin pain.

\section{Case presentation}

A 56 year-old man was diagnosed with asymptomatic left sided hydronephrosis while being investigated for rheumatoid arthritis. Investigations included ultrasonography, intravenous urography, retrograde uretero-pyelography, Computed tomography (CT) imaging, renography and screening for tuberculosis. Radiological appearances were not typical of classical pelvi-ureteric junction obstruction 
with normal funneling and ready contrast drainage into upper ureter. Isotope renography revealed a $25 \%$ split left kidney function with a poor response to frusemide diuresis. CT scan imaging showed ill defined fascial plains around the kidney and thickening around the renal hilum suggestive of localized inflammatory change (Figure 1). No surgical intervention was undertaken as the patient was asymptomatic with significant ischaemic heart disease. Two years later, he developed worsening intermittent left loin pain with increasing hydronephrosis, significant cortical thinning and marked deterioration of renal function. Following coronary artery bypass surgery, he opted for a left nephrectomy. Patient remains pain-free at one year follow-up.

Macroscopy showed a hydronephrotic kidney with areas of fibrosis adjacent to the renal pelvis and peri-renal fat. Microscopically, within the area of fibrosis, there were hypocellular interweaving thick collagen bundles with extensive hyalination intermingled with bland spindle cells. Inflammatory cells including lymphocytes, eosi- nophils and plasma cells were also found (Figure 2a-c). There were some irregular projections of this fibrous tissue into the adjacent fat.

Immunohistochemistry showed positivity for smooth muscle actin (Figure 2d), vimentin and CD34 (Figure 3a \&3b) but negativity for ALK-1 consistent with a histological diagnosis of IMT.

\section{Discussion}

Inflammatory pseudotumour of the kidney or IMT is a disease of young people and unknown etiology, affecting females more than males [1]. Differential diagnoses include malignant tumors such as renal cell carcinoma, sarcomatoid renal cell carcinoma, inflammatory fibrosarcoma, malignant fibrous histiocytoma, low grade neurogenic tumor, myxoid leimyosarcoma [2] and nonmalignant tumors such as angiomyolipoma, xanthogranuloma pyelonephritis and plasma cell granuloma [3]. Patients usually present with haematuria and/or abdominal pain. Clinical examination and radiological investiga-

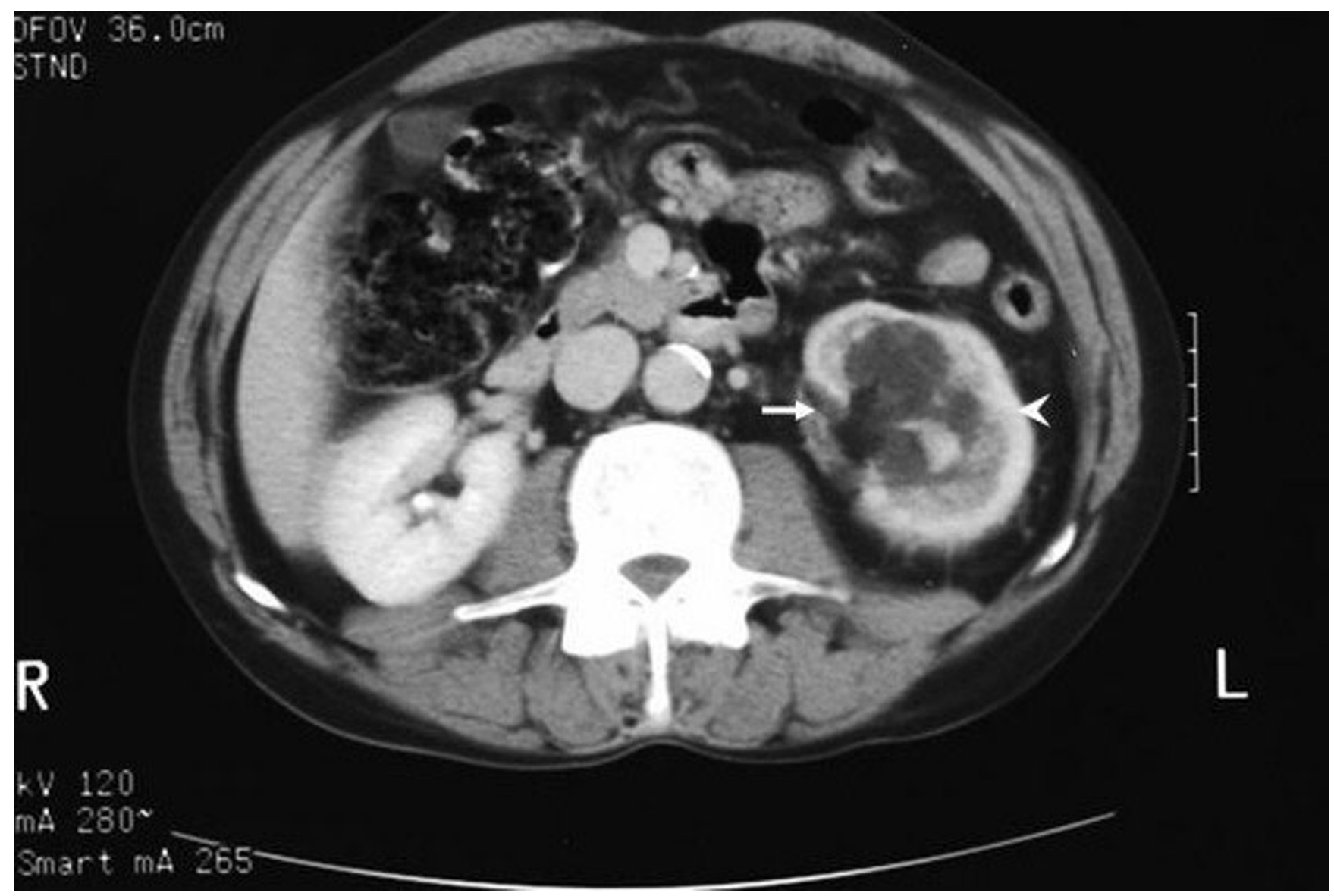

\section{Figure I}

CT scan showing PUJ obstruction (arrow) with ill defined fascial planes around the left kidney (arrow head) that is consistent with inflammation. 

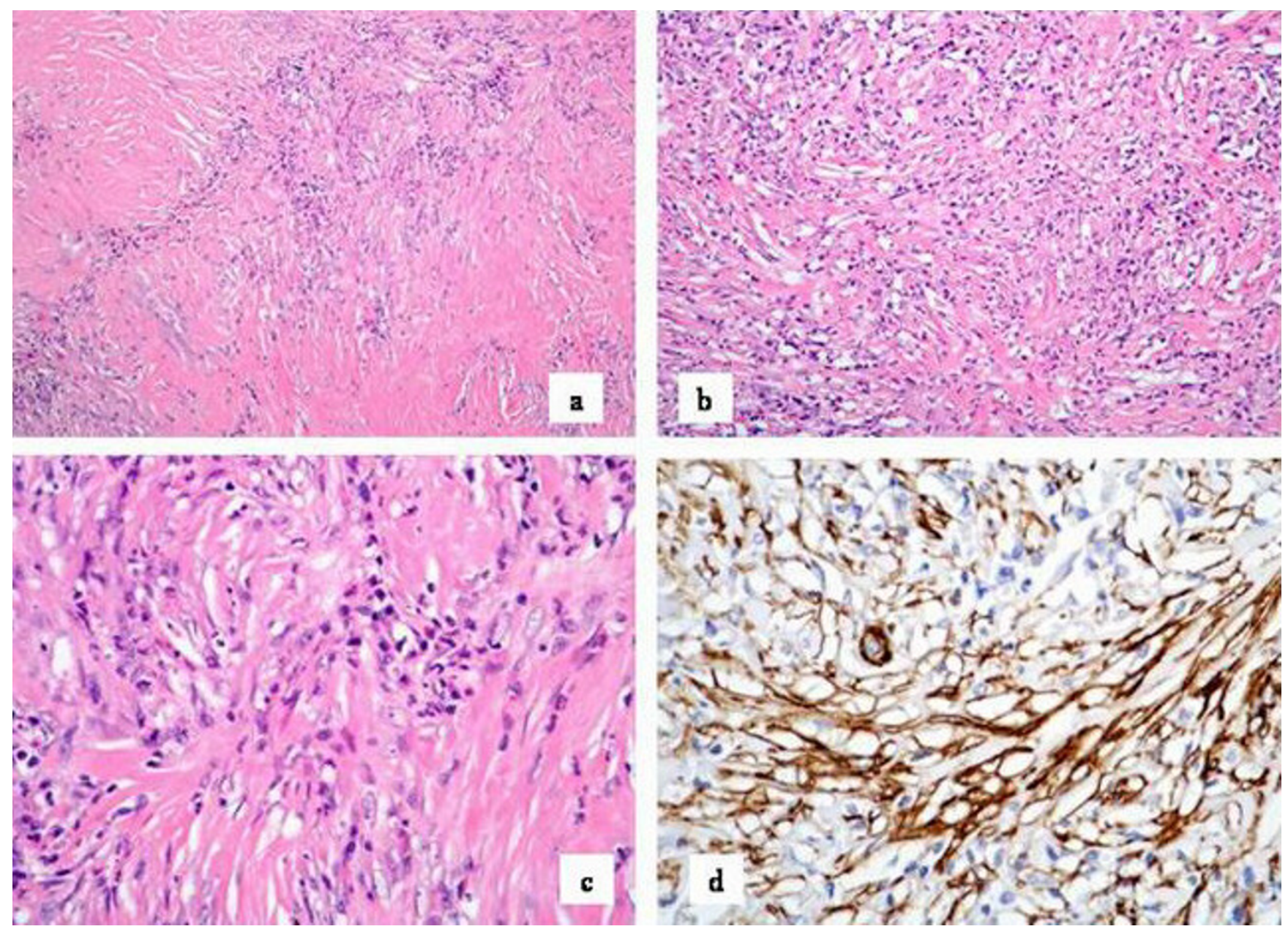

\section{Figure 2}

Photomicrograph showing a] Vaguely nodular areas of collagenous tissue with scattered spindle cells and darker inflammatory cells at the edges of the collagenous nodules. $(H \& E, \times 60)$. b] More cellular area where there is a pale, eosinophilic collagenous background with pale spindle cells and darker inflammatory cells scattered without any particular pattern. (H \& E, I50). c] Pale nuclei of the spindle cells with scattered darker lymphocytes and plasma cells in a pale, eosinophilic background. (H \& E, $\times 250)$. d] Immunocytochemical labeling for smooth muscle actin, shown as brown strands of filamentous material in the cytoplasm of the myofibroblasts. (Immunocytochemical labeling, smooth muscle actin, $\times 250$ ).

tions are often inconclusive. It is difficult to obtain enough tissue by CT-guided fine needle aspiration to make a definitive histological diagnosis $[3,4]$ and most diagnoses have been made at the time of surgical intervention.

Histologically, they consist of proliferation of spindle cells admixed with various amounts of lymphocyplasmacytic infiltrate with consistent expression of vimentin and smooth muscle actin $[5,6]$. These tumors are strongly positive for CD 34 reactivity. ALK is only positive in $50 \%$ and it generally tends to be positive in younger patients [7]. The architectural appearances vary and have been described as a patternless pattern [2].
IMT generally tend to lack severe cytologic atypia and less mitosis than sarcomas and also generally tend to be negative for p53 which is positive in sarcomas [2].

Local recurrences and malignant transformation have been reported in a small subset of patients, but these generally tend to be where complete resection has been impossible $[1,8,9]$.

We report a rare case of an inflammatory pseudotumour of the kidney. It is unique in that the patient presented with painless hydronephrosis and progressive deterioration in renal function while developing worsening loin pain. We suspect that the inflammatory reaction could 

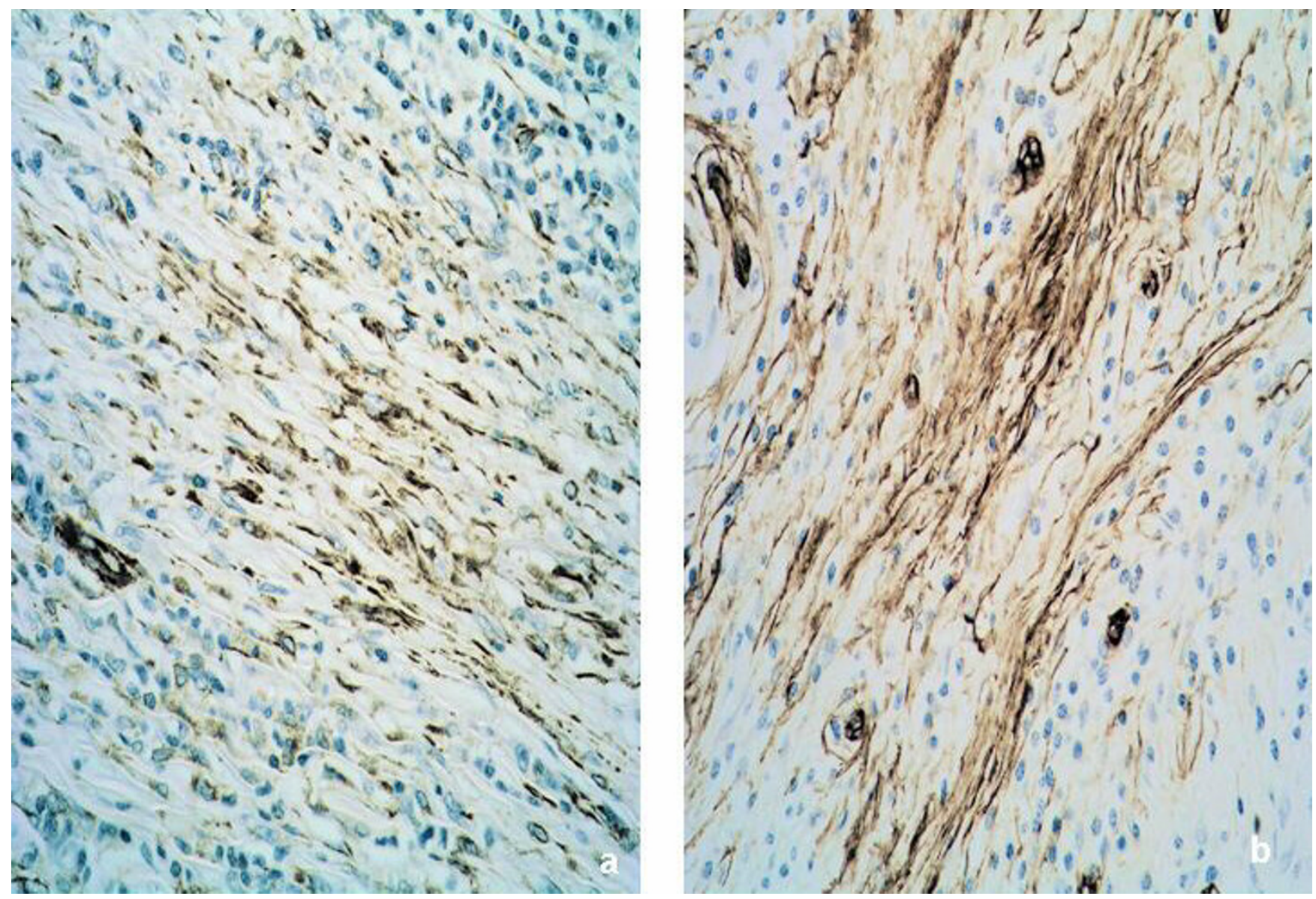

\section{Figure 3}

Immunocytochemical labeling for vimentin (3a) and CD34 (3b) showing spindle cells within the tumour positive for vimentin and CD 34. $(\times 250)$

have occurred as a consequence of chronic pelvi-ureteric junction obstruction.

\section{Conclusion}

We report a rare case of an inflammatory pseudotumor of the kidney. It is unique in that the patient presented with painless hydronephrosis and progressive deterioration in renal function while developing worsening loin pain. We suspect that the inflammatory reaction could have occurred as a consequence of chronic pelvi-ureteric junction obstruction.

\section{Competing interests}

The author(s) declare that they have no competing interests.

\section{Authors' contributions}

JP, DRS and RM conceptualized the case report, conducted the literature search. DRS, JP, RM and ADD were involved in direct clinical management of the patient.
GHRL conducted the radiological investigations and TRH carried out the pathological analysis and immunohistochemistry. All authors helped to draft the manuscript. All authors read and approved the final manuscript.

\section{Acknowledgements}

Written consent of patient was obtained for publication of this case report

\section{References}

I. Bildirici K, Donmez T, Gurlek E: Inflammatory Pseudotumor of the Kidney. Int Urol Nephrol 2004, 36:14I-I43.

2. Gelb $A B$, Simmons ML, Weidner N: Solitary fibrous tumor involving the renal capsule. Am J Surg Pathol I 996, 20:1288-I 295.

3. Bell ND, Jimmie N, Gavras : Renal Inflammatory Pseudotumor. South Med J 1998, 91 : I050-1053.

4. Ishikawa T, Fujisawa M, Tamada H, Inoue T, Shimatani N: Inflammatory pseudotumor of the kidney. Int J Urol 2004, I I I:337-339.

5. Ro JY, Ayale AG, Ordonez NG: Pseudosarcomatous fibromyxoid tumor of the urinary bladder. Am J Clin Pathol 1986, 86:583-590.

6. Kapusta LR, Weiss MA, Ramsay J, Lopez-Beltran A, Srigley JR: Inflammatory Myofibroblastic Tumors of the Kidney - A clinicopathologic and Immunohistochemical Study of 12 cases. Am J Surg Pathol 2003, 27:658-666. 
7. Cook JR, Dehner LP, Collins MH, Ma Z, Morris SW, Coffin CM, Hill DA: Anaplastic lymphoma kinase (ALK) expression in the inflammatory myofibroblastic tumor: a comparative immunohistochemical study. Am J Surg Pathol 200I, 25: I364-I37I.

8. Coffin CM, Watterson J, Priest JR, Dehner LP: Extrapulmonary inflammatory myofibroblastic tumor (inflammatory pseudotumor): a clinicopathologic and immunohistochemical study of 84 cases. Am J Surg Pathol 1995, 19:859-872.

9. Coffin CM, Humphrey PA, Dehner LP: Extrapulmonary inflammatory myofibroblastic tumor: a clinical and pathologic survey. Semin Diagn Pathol 1998, 15:85- I0I.

Publish with Bio Med Central and every scientist can read your work free of charge

"BioMed Central will be the most significant development for disseminating the results of biomedical research in our lifetime. " Sir Paul Nurse, Cancer Research UK

Your research papers will be:

- available free of charge to the entire biomedical community

- peer reviewed and published immediately upon acceptance

- cited in PubMed and archived on PubMed Central

- yours - you keep the copyright

Submit your manuscript here:

http://www.biomedcentral.com/info/publishing_adv.asp 